\title{
The Use of Remote Sensing and Geographic Information System Techniques to Determine Relationships between Land Use and Landform
}

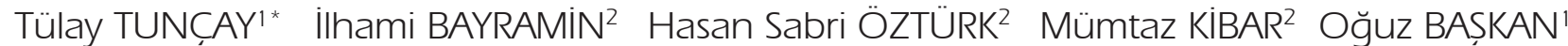

'Soil Fertilizer and Water Resources Center Research Institute, Ankara-Turkey

¿Univ. of Ankara, Faculty of Agriculture, Dept. of Soil Science and Plant Nutrition, Ankara-Turkey

\author{
*Corresponding author e-mail (Sorumlu yazar): tulaytuncay@gmail.com \\ Received date (Geliș tarihi): 0 1.07.2014 \\ Accepted date (Kabul tarihi): 09.07.2014
}

\begin{abstract}
This paper reports on an exercise in obtaining landform information from a Digital Elevation Model (DEM) using Geographic Information Systems (GIS), and relating land cover information from satellite data to the landform classes and soil formation. The Beypazari area (northern Turkey) was chosen because of its varied landforms, land use and land cover. Soil samples, collected from forty-four soil pits were analysed and classified. Most of the soils were classified as Entisol and Inceptisol. In general, the effect of parent material on soil formation was dominated by landform. Landsat TM data were classified to determine land cover categories, and DEM data were analysed to determine landform classes. A strong correlation was found between landform and land cover. The expected results were observed between the soil formation and landform. Inceptisols were generally distributed over the hills and mountains where higher elevation and steep slopes are. As anticipated, forest, rangelands and barren lands were strongly associated with areas of high elevation and steep slopes. However, contrary to expectations, much of the agricultural land was also associated with hill and mountain areas.

The Landform classification with DEM analyses was very successful except for the narrow valleys located in hilly areas. To separate or identify narrow colluvial valleys in these hilly areas, the different resolution and window size for neighbouring have to be tested for the landform classification. The Landsat TM data were very useful for the 1st level land cover study. On the other hand, higher spatial resolution $(<30 \mathrm{~m})$ and multi-temporal data were needed especially in narrow valleys where irrigated areas and trees were not separated successfully.
\end{abstract}

Key Words: Digital elevation model (DEM), GIS, land cover, landform, remote sensing, soil formation

\section{Arazi Kullanımı ve Arazi Șekli Arasındaki İlișkilerin Belirlenmesi için Uzaktan Algılama ve Coğrafi Bilgi Sistemi Tekniklerinin Kullanımı}

Öz

Bu makalede, Coğrafi Bilgi Sistemi kullanarak Sayısal Yükselti Modelinden elde edilen arazi șekilleri hakkında bilgilerin elde edilmesi ve uydu verisinden elde edilen arazi örtüsünün arazi șekilleri sınıfları ve toprak olușumu ile olan ilișkisini açıklamaktadır. Beypazarı ve çevresi çeșitli arazi șekilleri, arazi kullanımı ve örtüsüne sahip olduğu için seçilmiștir. Proje alanından açılan 44 adet toprak profilinden alınan toprak 
örnekleri analiz edilmiș ve sınıflandırımıștır. Toprakların çoğu Entisol ve Inceptisol olarak sınıflandırılmıștır. Genellikle, toprak olușumu üzerine ana materyalin etkisi arazi șekli ile yönlendirilmiștir. Landsat TM verisi arazi örtüsü kategorilerini belirlemek için sınıflandıııımıș ve DEM verileri arazi șekilleri sınıflarını belirlemek için sınıflandırılmıștır. Arazi șekilleri ve arazi örtüsü arasında güçlü bir korelasyon bulunmuștur. Ayrıca, toprak olușumu ve arazi șekilleri arasında beklenen sonuçlar bulunmuștur. Inceptisol topraklar genel olarak yüksek ve dik eğimli dağlık ve tepelik alanlarda dağımıștır. Beklendiği gibi orman, meralar ve çıplak alanlar yüksek ve dik eğimli alanlarla güçlü bir șekilde ilișkilidir. Bununla birlikte, beklenenin aksine, tarımsal alanların çoğu aynı zamanda tepe ve dağılı alanlarda da belirlenmiștir.

Sayısal Yükseklik Modeli analizleri ile arazi șekli sınıflandırması dağlık alanlarda bulunan dar vadiler dıșında çok bașarılı olmuștur. Bu dağlık alanlardaki dar koluviyal vadileri ayırmak ve tanımlamak için, farkı yüksek çözünürlüklü sayısal yükselti modeli ile arazi șekli sınıflandırması test edilmelidir. Landsat TM verisinin I. seviye arazi örtüsü çalıșmaları için çok kullanıșlı olduğu belirlenmiștir. Diğer taraftan, yüksek konumsal çözünürlüklü $(<30 \mathrm{~m}$ ) ve çok-zamanlı verilerin özellikle sulanan alanları ve ağaçların bașarılı bir șekilde ayırt edilemediği dar vadilerde kullanılmasına intiyaç duyulmuștur.

Anahtar Kelimeler: Sayısal yükseklik modeli (SYM), CBS, arazi örtüsü, arazi șekli, uzaktan algılama, toprak olușumu

\section{INTRODUCTION}

Information on land cover and landform is essential for effective management of the environment and natural resources, and can contribute to environmental policy formulation when combined with other environmental data (Brabyn, 1998). In relatively remote landscapes, rural development is often a key issue; yet comprehensive field survey is impractical. Recent advances in satellite and computer technologies provide the possibility of processing large amounts of multi-source data, and facilitate the combination of spectral imagery with other environmental surveys (Bayramin, 1998). Developments in remote sensing (RS) and Geographic Information Systems (GIS) have led to the widespread production of land cover maps, whilst the volume of data from Earth observation satellites has enabled land cover inventories to be compiled for vast areas. Geographic information software has also made it easier to use the information from these inventories and to update them more rapidly.

Landforms are the product of long- and shortterm processes operating principally in response to climate, water, geology, tectonics and vegetation (Dikau et al., 1991). Land surface configuration is a complex geometry that, for management purposes, normally needs to be resolved into its component parts, elements or attributes (Hammond, 1954). Latterly, this has been accomplished by use of digital elevation models (DEM). Soil properties are of particular interest in landform classification, and changes in one or more soil forming factors in a landscape can help locate boundaries between different bodies of soil (Jenny, 1980). Thus, once the relationships among soils and landscape have been determined for an area, soil cover can be inferred by identifying the characteristic soillandscape unit (Swanson, 1990). Consequently, interpretive mapping of soil character has drawn upon RS, DEM and GIS data, at least as an adjunct to field survey (e.g. Klingebiel et al., 1987; Horvath et al., 1984; Lee et al., 1988; Stoner and Baumgardner, 1981; Su et al., 1989).

Showing geographic distribution of soils and other important landscape properties, and interpreting these for specific uses are the most important purposes of soil surveys. Forest and rangeland uses are general in mountainous areas, and therefore soil surveys are at smaller scales. In these areas, soil landscape relationships are complex because of large variation in local climates, vegetation, parent materials, and topography. Because of these complexities, landform, vegetation, or geologic characteristics are more often used for phase criteria than in detailed surveys in mountainous areas. Limited access reduces the efficiency of conventional mapping techniques. Not all map unit boundaries verified by transecting or traversing. Remote sensing and widely spaced observations with some traversing are used to predict soil and landscape features and for delineation of most 
map units Shovic and Mantagne (1985).

Smith and Verril (1998) hypothesized and reached the conclusion that based upon an analysis of present-day mapping of vernal pools, soils, and geomorphology, that the occurrence of vernal pools within the Central Valley can be correlated with specific types of soils, geologic formations, and landforms. Correlation of vernal pool landscapes with soils, geologic formations, and landforms may also provide a methodology for identification of characteristic hydrologic features, correlation with special-status species distribution, assessment of geodiversity and biodiversity, determination of suitability for restoration, and development of appropriate mitigation techniques, and construction density. They indicated that this approach facilitates optimal regional land-use planning, establishment of preserves, and sitting of mitigation banks.

Catenary soil development occurs in many landscapes in response to the way water moves through and over the landscape. Furthermore, terrain attributes can characterize these flow paths and, therefore, soil attributes such as A horizon thickness, organic matter content, $\mathrm{pH}$, extractable $P$, silt and sand content. This represents an incorporation of finer scale process-based information relating to soil formation patterns in the landscape (Moore et al, 1993).

In the present paper, we discuss ways of obtaining landform information from a DEM and synthesizing it with land cover information obtained from satellite data, and interpreting it on geology and landscape basis, which is meaningful to users and soil surveyors.

\section{MATERIAL AND METHODS}

The Beypazari-Ankara area (Figure 1) was selected for this investigation because of its diverse landforms (alluvial plains, plateaus, high hills and mountains) and different land use and land cover units (agricultural lands, forest lands, bare lands, range lands, etc.).

Data were obtained from a Landsat 5 TM scene, acquired on 9th September 1998 (Figure 2), and a 3-arc second DEM; computation was carried out using NT versions of Arc Info'T, ArC $V_{\text {View }}{ }^{\mathrm{TM}}$ and Erdas Imagine ${ }^{\mathrm{TM}}$ software.

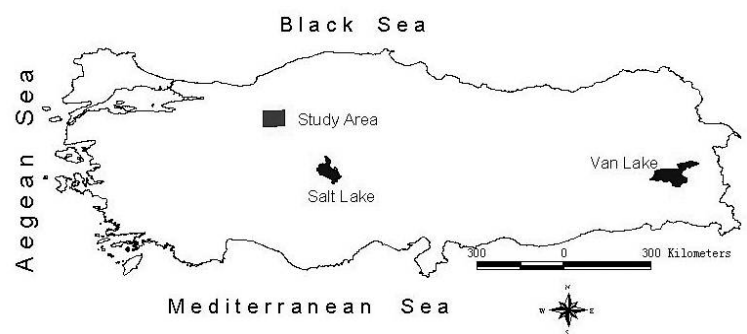

Figure 1. Location of the Study Area

Sekil 1. Calıșma alanının konumu

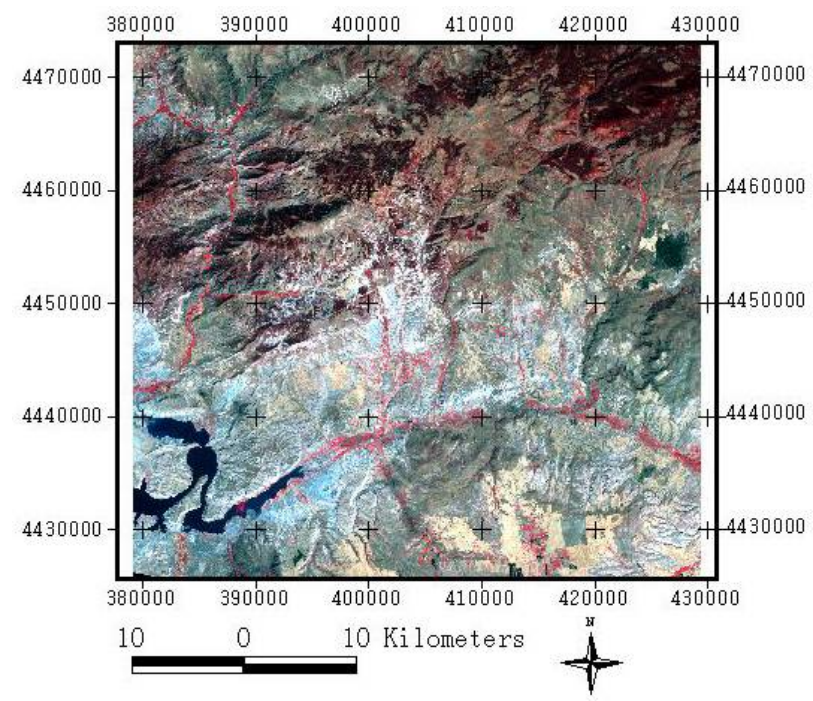

Figure 2. Landsat 5 TM scene of the study area (acquired on $9^{\text {th }}$ September 1998)

Sekil 2. Çalıșma alanı Landsat5 TM görüntüsü

Georefencing and geocoding processes were applied to Landsat TM data and the image was geometrically corrected and rectified using 1: 25,000 scale topographic maps and GPS data collected on the field to UTM map projection system with International 1909 Spheroid and European 1950 datum. The histogram equalization technique was applied to the image for radiometric enhancement. The Normalized Difference Vegetation Index (NDVI) (defined by Tucker et al., 1985), was obtained using bands 4 (Near Infrared) and 3 (Red) of Landsat TM data and new data set was created adding NDVI band to the original 7 band data set as the $8^{\text {th }}$ band.

After visual interpretation, different sub-sets of the image were prepared and downloaded to a laptop computer for use in the field. To support the interpretation of land use and land cover categories, ground truth information was collected in the field with the aid of a Magellan Promax 5 Global Positioning System, and the classification system of the United States Geological Survey (Anderson et al., 1976) was applied. 
For the Landsat TM data classification, training signatures were prepared on the basis of field observations. A total of 185 training signatures (29.350 pixels) for all land cover classes were selected and classification accuracies were tested by contingency matrix analysis, and the procedure was repeated several times to maximize accuracy. After being eliminated of signatures with a low accuracy and selecting new ones, all signatures were merged into eight land cover signature sets, and the contingency analyses were repeated to confirm high levels of accuracy. Total of 25.360 training pixels out of 25.269 pixels for eight land cover land use classes were labelled correctly and $99.64 \%$ overall accuracy was obtained. After having high classification accuracies (for training sets) and finishing training procedure of Landsat TM data, we classified overall image using the Maximum Likelihood Decision Rule (MLH) algorithm.

A total of 11 DEM data sheets (3-Arc second DEM), with $10 \mathrm{~m}$ resolution grid data, were registered to UTM map projection systems and merged into one dataset using the Arc/ Info Grid tool. A re-sampling process was applied to a $10 \mathrm{~m}$ dataset and a $200 \mathrm{~m}$ - resolution dataset was created using the nearest neighbour algorithm as indicated by Dikau et al., (1991). The landform classification scheme (Table 1) and technique (Table 2) of Dikau et al., (1991), based on elevation and slope, were adopted. The DEM for each dataset was converted to a drape by moving a window of $3 \times 3$ elevation points across the dataset, and slopes were divided into four groups (<20\%, 20-50\%, 50-80\%, >80\%). A moving window was moved across the dataset to determine the local relief (i.e. the difference between maximum and minimum elevation), which was allocated to one of five classes. The profile type, an index relating gently sloping areas to an upland or lowland situation, was calculated for the study area. The three layers - slope, local relief and profile type - were combined to obtain landform classes, which were then grouped into major landform types. The landform classes obtained from the DEM data, and land cover classes obtained from Landsat TM data, were merged in order to analyse the distribution and relationships between the land cover and landform units.

A total of 11 digital geologic map sheets were merged into the one map. Distribution of the major geological formations is presented in Figure 3 and Table 3. In the Beypazari region, metamorphic rocks of the Middle Sakarya Massive are intruded by a low temperatured and shallow emplaced batholite. Composition of the batholite body shows variation from granite to diorite. These granitic outcrops (Tbg), dominant at the southern part of the Kirmir Stream, are probably connected to other Anatolian granitic complexes. Granite principally consists of quartz, plagioclase, orthoclase, and minor amphibole, biotite, chlorite, zircon, sphene, appatite and opaque minerals. Plagioclase and orthoclase show sericitization, whereas biotite shows chloritization (Helvaci and Bozkurt, 1994). Quaternary Fluvial (Oa) and Pliocene and Miocene aged sedimentary deposits (Tur-Tor-Tha) are the most extended geologic formations in the study area. These formations (Qa-Tur-Tor-Tha) are named as Kirmir formation. Kirmir formation consists of alternation of shale, gypsum, breccia, limestone, travertine, conglomerate, mudstone, sandstone

Table 1. Landform classification schema (Dikau et al., 1991)

Çizelge 1. Arazi șekli sınıflandırma șeması (Dikau et al., 1991)

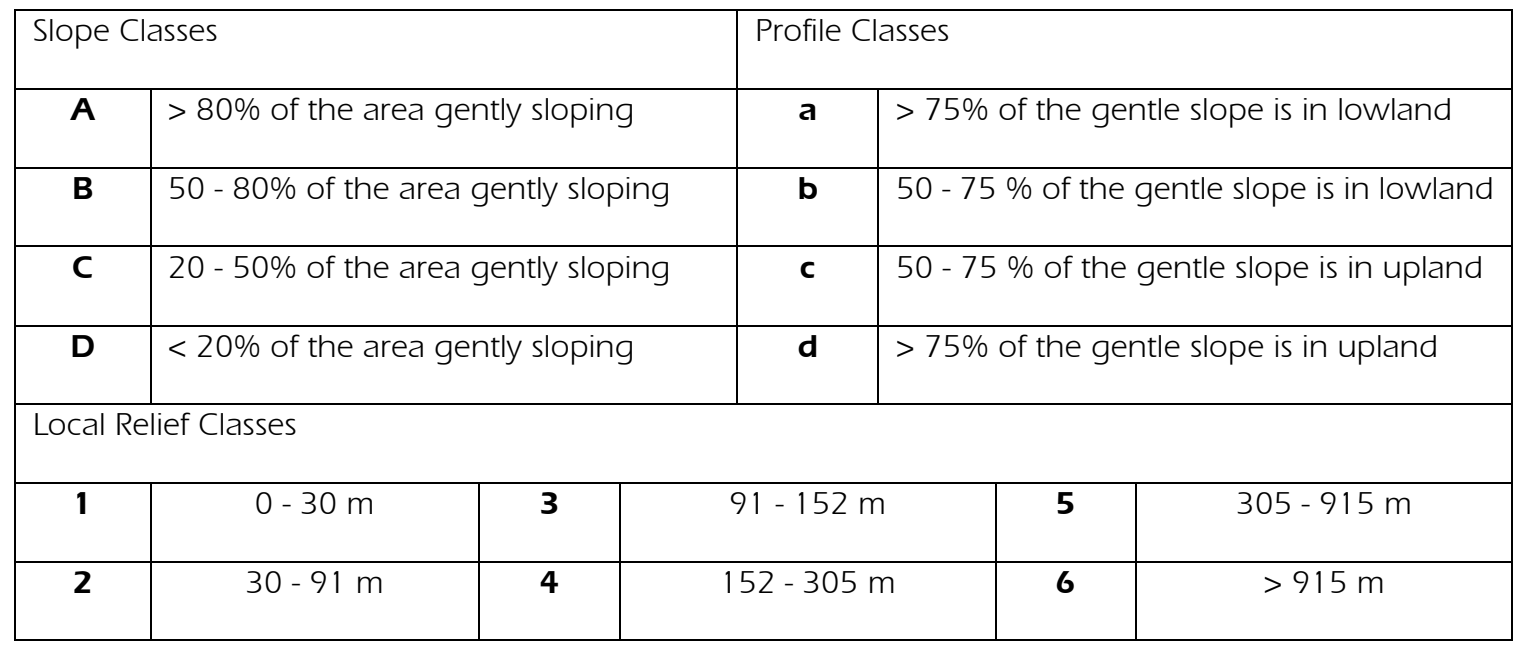


and clayey beds. These units include three different facieses, based on sedimentary properties of gypsum lopen lake with short evaporitic faces, marginal swamps with evaporitic ground water, closed lake with evaporitic lake water). These different stages of gypsum occurrences primarily resulted from climatic changes from humid to arid. Tectonic is also thought to play a role on the regression of the lake area (Karadenizli, 1995). Volcanic rocks are located on northern part of the study area where higher elevations are. Basalt, andesite, dacite, rhyolite, tuff and agglomerate (TiTu-Td) are the major Miocene volcanic rocks (Siyako, 1983). Especially pyroclastics (breccia, tuff and agglomerate) are more weathered than other volcanics, and they formed volcanic originated clay, clayey silt, sand, pebbles and blocky materials. These loosely cemented pyroclastics are not resistant to weathering compared to the other volcanics and very sensitive to atmospheric events such as wind and rain. Narrow and deep valleys are formed on these sloping areas. Because of these properties, shallow soil profiles were observed in these areas.

Following landform and land cover data integration process, landform layer was combined with geological map and soil-land-units were generated. Each soil land units was analysed according to their coverage and land cover-use and soil profile pit locations were determined. Forty-four soil pits were opened and sampled to determine physical and chemical properties of the study area soils as Soil Survey Staff (1993). After laboratory analyses (Soil Survey Staff, 1996), soils were classified using Soil Taxonomy (1999).

Table 2. The landform classification used in this study (Dikau et al., 1991)

Çizelge 2. Çalıșmada kullanılan arazi șekli sınıflandırması (Dikau et al., 1991)

\begin{tabular}{|c|c|c|c|}
\hline $\begin{array}{c}\text { Major Landform } \\
\text { Type }\end{array}$ & Landform Classes & $\begin{array}{l}\text { Landform subclass } \\
\text { Code }\end{array}$ & \\
\hline \multirow{4}{*}{ Plains (PLA) } & Flat or nearly flat & Ala, Alb, Alc, Ald & 1 \\
\hline & Smooth plains with some local relief & $A 2 a, A 2 b, A 2 c, A 2 d$ & 2 \\
\hline & Irregular plains with low relief & B1a, B1b, B1c, B1d & 3 \\
\hline & Irregular plains with moderate relief & B2a, B2b, B2c, B2d & 4 \\
\hline \multirow{4}{*}{$\begin{array}{l}\text { Tablelands } \\
\text { (TAB) }\end{array}$} & Table lands with moderate relief & $A 3 c, A 3 d, B 3 c, B 3 d$ & 5 \\
\hline & Table lands with considerable relief & $A 4 c, A 4 d, B 4 c, B 4 d$ & 6 \\
\hline & Table lands with high relief & $\mathrm{A} 5 \mathrm{c}, \mathrm{A} 5 \mathrm{~d}, \mathrm{~B} 5 \mathrm{c}, \mathrm{B} 5 \mathrm{~d}$ & 7 \\
\hline & Table lands with very high relief & $A 6 c, A 6 d, B 6 c, B 6 d$ & 8 \\
\hline \multirow{4}{*}{$\begin{array}{l}\text { Plains with Hills or } \\
\text { Mountains (PHM) }\end{array}$} & Plains with hills & A3a, A3b, B3a, B3b & 9 \\
\hline & Plains with high hills & A4a, A4b, B4a, B4b & 10 \\
\hline & Plains with low mountains & A5a, A5b, B5a, B5b & 11 \\
\hline & Plains with high mountains & A6a, A6b, B6a, B6b & 12 \\
\hline \multirow{6}{*}{$\begin{array}{l}\text { Open Hills and } \\
\text { Mountains } \\
\text { (OPM) }\end{array}$} & Open very low hills & $\mathrm{Cla}, \mathrm{Clb}, \mathrm{Clc}, \mathrm{Cld}$ & 13 \\
\hline & Open low hills & C2a, C2b, C2c, C2d & 14 \\
\hline & Open moderate hills & C3a, C3b, C3c, C3d & 15 \\
\hline & Open high hills & C4a, C4b, C4c, C4d & 16 \\
\hline & Open low mountains & C5a, C5b, C5c, C5d & 17 \\
\hline & Open high mountains & C5a, C5b, C5c, C5d & 18 \\
\hline \multirow{6}{*}{$\begin{array}{l}\text { Hills and } \\
\text { Mountains } \\
\text { (HMO) }\end{array}$} & Very low hills & D1a, D1b, D1c, D1d & 19 \\
\hline & low hills & D2a, D2b, D2c, D2d & 20 \\
\hline & Moderate hills & D3a, D3b, D3c, D3d & 21 \\
\hline & High hills & D4a, D4b, D4c, D4d & 22 \\
\hline & Low mountains & D5a, D5b, D5c, D5d & 23 \\
\hline & High mountains & D5a, D5b, D5c, D5d & 24 \\
\hline
\end{tabular}



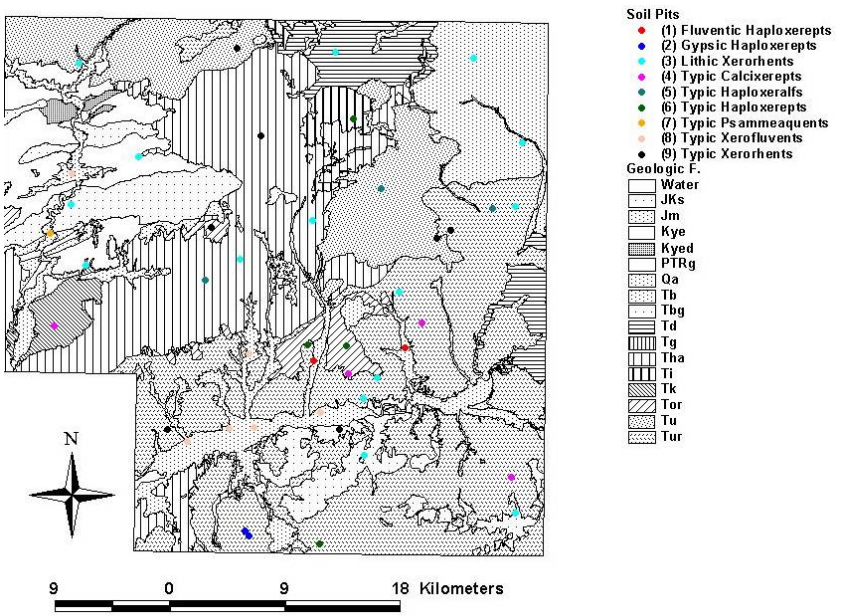

Figure 3. Distribution of the major geological formations in the study area

Șekil 3. çalıșmadaki temel jeolojik formasyonların dağılımı

Monthly temperature and precipitation values of the Ankara - Beypazari Climate Station $\left(40010^{\prime} \mathrm{N}, 31056^{\prime} \mathrm{E}\right.$, and $682 \mathrm{~m}$ above sea level) were analysed and soil moisture and temperature regimes were determined according to the Thorntwaite (1948) and Soil Taxonomy (1999). According to Thornthwaite (1948), study area was classified as $\left(\mathrm{C}_{2} \mathrm{~B}_{2}^{\prime} \mathrm{S}_{2} \mathrm{D}_{3}{ }^{\prime}\right)$ which is dry to semi-arid, 2nd degree meso-thermal, under sea climate effect that has water deficit during summer season. Xeric soil moisture and Mesic temperature regimes were determined for the study area according to the soil-water budget analyses. According to these results, study area is under effect of Mediterranean climate with hot and dry summers and cold and rainy winters. In general, leaching occurs during rainy winter times when low evapotranspiration occurs.

Table 3. Distribution of the geologic formations of the study area

Çizelge 3. Çalıșma alanındaki jeolojik olușumların dağı̆ımı

\begin{tabular}{|l|c|c|l|l|l|}
\hline \multicolumn{7}{|c|}{ Geologic Formations } \\
\hline Symbol & ha & $\%$ & Symbol & ha & $\%$ \\
\hline Kyed & 632.9 & 0.4 & Td & 7405.4 & 4.6 \\
\hline Jm & 671.2 & 0.4 & Kye & 8140.5 & 5.0 \\
\hline Ti & 2365.8 & 1.5 & Tb & 11450.0 & 7.0 \\
\hline Tk & 2379.8 & 1.5 & Oa & 13836.1 & 8.5 \\
\hline PTRg & 2727.6 & 1.7 & Tu & 16898.4 & 10.4 \\
\hline Tor & 3821.0 & 2.4 & Tha & 33752.8 & 20.8 \\
\hline Tbg & 6090.0 & 3.7 & Tur & 45512.2 & 28.0 \\
\hline JKs & 6731.3 & 4.1 & Total & 162414.9 & ha \\
\hline
\end{tabular}

\section{RESULTS}

The resulting classified image shows that the main land covers/uses are rangelands (30.4\%), forest areas (29.2\%), barren lands (23.0\%), agriculture (17.3\%), and very little water surface $(0.01 \%)$. Results were checked in the field at 176 randomly chosen control points with GPS, yielding an overall classification accuracy of $72.7 \%$, though this was slightly lower for irrigated areas where the inclusion of some stream banks and their associated trees was a significant source of error. Although the results were acceptably accurate, certain sources of error were identified. These included data preparation errors, loss of information or introduction of noise where angle of solar incidence in steeply sloping areas, and problems in separating forest and agriculture in narrow valleys. Land cover classes (Figure 4) were regrouped according to the USGS system (Level I) into five classes (Table 4) to integrate with landform.

Distribution of landform units and major landform types (Table 5) was then determined using Dikau et al's (1991) schema. A 3D view of the study area was derived from the DEM, and this was compared visually with 1:25,000 topographic maps to evaluate landform classification. The major landform types were plains $(2.76 \%)$, tablelands $(0.85 \%)$, plains with hills or mountains $(7.55 \%)$, open hills and mountains (21.94\%) and hills and mountains (66.91\%).

Superimposing the major land cover classes onto major landform types shows a strong correlation, especially for forest, rangelands and barren lands (Table 6). Thus, 97.9\% of the forested area is distributed in hills and mountains, and is associated with higher elevation and steep slopes. Similar results were observed for rangelands and barren lands, with $90.8 \%$ and $88.2 \%$, respectively, distributed in class 4 (open hills and mountains) and class 5 (hills and mountains) characterised by moderate and higher elevation, and moderate to steep slopes. 


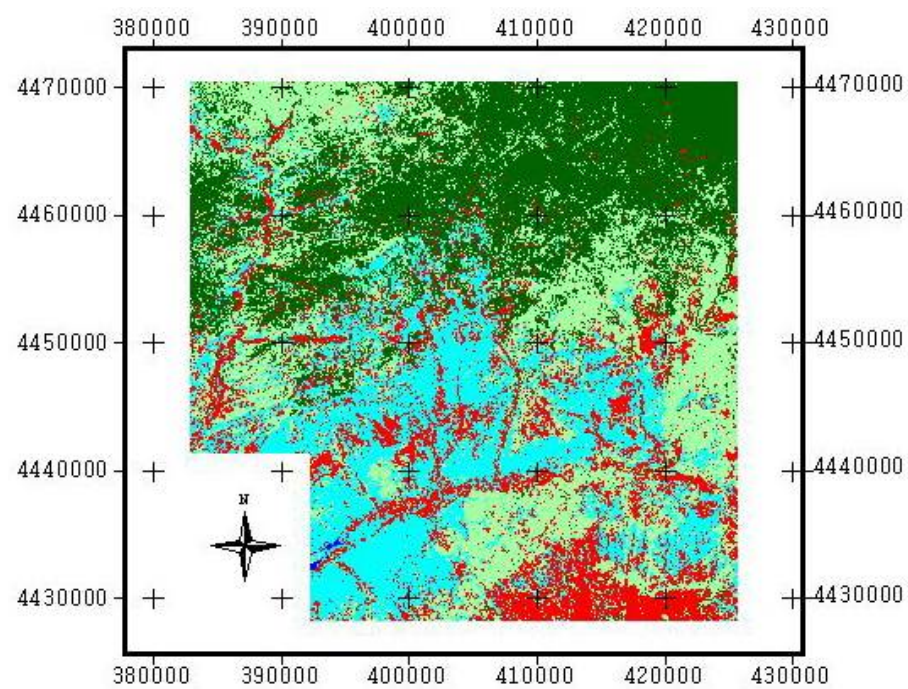

Land Use - Land Cover Classes

Water Surfaces

Forest

Range Lands

Barren Lands

Agricultural Lands

Figure 4. Land cover classes of the study area

Şekil 4. Çalıșma alanıının arazi örtüsü sınıfları

Table 4. The distribution of the land cover - land use classes obtained from Landsat TM image classification

Çizelge 4. Landsat TM görüntüsünün sınıflamasından elde edilen arazi örtüsü - arazi kullanımının dağıımı

\begin{tabular}{|c|l|c|c|c|c|}
\hline & & \multicolumn{2}{|c|}{ Area } & \multicolumn{2}{c|}{ Area } \\
\hline Class Code & Land Cover \& Use Class & ha & $\%$ & ha & \% \\
\hline C1 & Water Surfaces & 89.2 & 0.1 & C1 & 0.1 \\
\hline C2 & Forest (Shrubs \& Brushes) & 37435.1 & 22.2 & C2 & 29.2 \\
\cline { 1 - 3 } C3 & Forest (high trees) & 11866.9 & 7.0 & & \\
\hline C4 & Range Lands & 51345.3 & 30.4 & C3 & 30.4 \\
\hline C5 & Barren Lands & 38791.7 & 23.0 & C4 & 23.0 \\
\hline C6 & Agricultural Lands (Fallowing) & 7157.3 & 4.2 & & \multirow{2}{*}{ C5 } \\
\cline { 1 - 3 } C7 & Agricultural Lands (Dry Farming) & 11214.4 & 6.6 & & \\
\hline C8 & Agricultural Lands (Irrigated Areas) & 10753.3 & 6.4 & & \\
\hline
\end{tabular}

However, only $29.2 \%$ of agricultural lands are distributed in suitable landforms for agriculture (plains, table lands, and plains with hills or mountains), and the remainder in classes 4 and 5, which have severe erosion problems and soil depth limitations. To understand the effect of landform and parent material on soil formation, 44 soil pits were opened and classified according to the Soil Taxonomy (1999) in the study area. Distribution of the soils on different geological formations, land use - land cover units and landform classes is presented in Table 7, and cross-section showing some relationships between soils, geologic formations, and landforms in the study area is shown in Figure 5. 


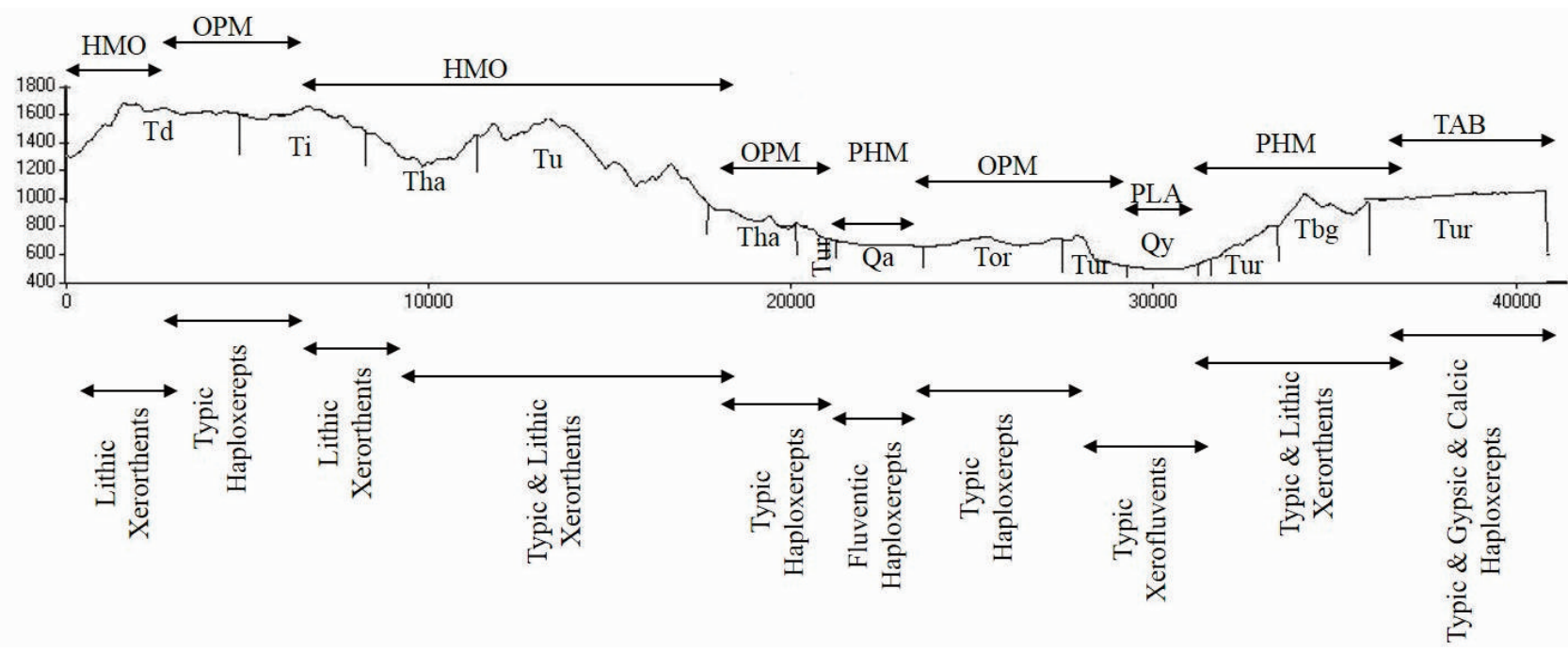

Figure 5. Cross-section showing some relationships between soils, geologic formations, and landforms in the study area Șekil 5. Çalıșma alanındaki topraklar, jeolojik formasyonlar ve arazi șekilleri arasındaki bazı ilișkileri gösteren kesit

Table 5. Distribution of the landform classes and major landform types

Çizelge 5. Arazi șekli sınıflarının dağıımı ve temel arazi șekil tipleri

\begin{tabular}{|c|c|c|c|c|c|c|c|}
\hline \multirow[t]{2}{*}{ LF Type } & \multirow{2}{*}{$\begin{array}{c}\text { LF } \\
\text { Class } \\
\end{array}$} & \multicolumn{2}{|c|}{ DEM } & \multirow[t]{2}{*}{ LF Type } & \multirow{2}{*}{$\begin{array}{c}\text { LF } \\
\text { Class }\end{array}$} & \multicolumn{2}{|l|}{ DEM } \\
\hline & & (ha) & $\%$ & & & (ha) & $\%$ \\
\hline \multirow{4}{*}{$\begin{array}{l}\mathbf{P} \\
\mathbf{L} \\
\mathbf{A}\end{array}$} & 1 & 3 & 0.00 & \multirow{6}{*}{$\begin{array}{l}O \\
\mathbf{P} \\
\mathbf{M}\end{array}$} & 13 & 59 & 0.03 \\
\hline & 2 & 1975 & 1.17 & & 14 & 592 & 0.35 \\
\hline & 3 & 77 & 0.05 & & 15 & 9440 & 5.60 \\
\hline & 4 & 2595 & 1.54 & & 16 & 21616 & 12.82 \\
\hline \multicolumn{2}{|c|}{ Total } & 4649 & 2.76 & & 17 & 5303 & 3.14 \\
\hline \multirow{4}{*}{$\begin{array}{l}\mathbf{T} \\
\mathbf{A} \\
\mathbf{B}\end{array}$} & 5 & 977 & 0.58 & & 18 & & \\
\hline & 6 & 449 & 0.27 & \multicolumn{2}{|c|}{ Total } & 37009 & 21.94 \\
\hline & 7 & & & \multirow{6}{*}{$\begin{array}{l}\mathbf{H} \\
\mathbf{M} \\
\mathbf{O}\end{array}$} & 19 & 7236 & 4.29 \\
\hline & 8 & & & & 20 & 294 & 0.17 \\
\hline To & & 1426 & 0.85 & & 21 & 1816 & 1.08 \\
\hline \multirow{4}{*}{$\begin{array}{l}\mathbf{P} \\
\mathbf{H} \\
\mathbf{M}\end{array}$} & 9 & 8760 & 5.19 & & 22 & 18786 & 11.14 \\
\hline & 10 & 3914 & 2.32 & & 23 & 83856 & 49.72 \\
\hline & 11 & 55 & 0.03 & & 24 & 853 & 0.51 \\
\hline & 12 & & & \multicolumn{2}{|c|}{ Total } & 112840 & 66.91 \\
\hline \multicolumn{2}{|c|}{ Total } & 12729 & 7.55 & & & & \\
\hline
\end{tabular}


Table $\mathbf{6}$. The distribution of the major land cover \& land use classes on major landforms.

Çizelge 6. Temel arazi șekli üzerindeki temel arazi örtüsü \& arazi kullanımı sınıflarının dağıımı

\begin{tabular}{|c|c|c|c|c|}
\hline \multirow[b]{2}{*}{$\begin{array}{c}\text { Major Landform } \\
\text { Types }\end{array}$} & \multirow[b]{2}{*}{$\begin{array}{c}\text { Major Land } \\
\text { Cover \& Use } \\
\text { Classes }\end{array}$} & \multicolumn{3}{|c|}{ Coverage } \\
\hline & & ha & $\begin{array}{c}\% \\
\text { (among each class) }\end{array}$ & $\%$ (in total) \\
\hline 1 & 1 & 3.0 & 3.3 & 0.0 \\
\hline 3 & 1 & 39.5 & 44.2 & 0.0 \\
\hline 4 & 1 & 16.7 & 18.7 & 0.0 \\
\hline 5 & 1 & 30.1 & 33.7 & 0.0 \\
\hline \multicolumn{2}{|c|}{ Sub Total } & 89.3 & 100.0 & 0.0 \\
\hline 1 & 2 & 153.3 & 0.3 & 0.1 \\
\hline 2 & 2 & 34.5 & 0.1 & 0.0 \\
\hline 3 & 2 & 833.9 & 1.7 & 0.5 \\
\hline 4 & 2 & 2706.8 & 5.5 & 1.6 \\
\hline 5 & 2 & 45573.7 & 92.4 & 27.0 \\
\hline \multicolumn{2}{|c|}{ Sub Total } & 49302.0 & 100.0 & 29.2 \\
\hline 1 & 3 & 982.4 & 1.9 & 0.6 \\
\hline 2 & 3 & 384.9 & 0.7 & 0.2 \\
\hline 3 & 3 & 3270.9 & 6.4 & 1.9 \\
\hline 4 & 3 & 11412.0 & 22.2 & 6.8 \\
\hline 5 & 3 & 35295.1 & 68.7 & 20.9 \\
\hline \multicolumn{2}{|c|}{ Sub Total } & 51345.3 & 100.0 & 30.4 \\
\hline 1 & 4 & 709.7 & 1.8 & 0.4 \\
\hline 2 & 4 & 217.6 & 0.6 & 0.1 \\
\hline 3 & 4 & 3650.6 & 9.4 & 2.2 \\
\hline 4 & 4 & 13299.3 & 34.3 & 7.9 \\
\hline 5 & 4 & 20914.5 & 53.9 & 12.4 \\
\hline \multicolumn{2}{|c|}{ Sub Total } & 38791.7 & 100.0 & 23.0 \\
\hline 1 & 5 & 2800.2 & 9.6 & 1.7 \\
\hline 2 & 5 & 788.9 & 2.7 & 0.5 \\
\hline 3 & 5 & 4934.4 & 16.9 & 2.9 \\
\hline 4 & 5 & 9574.7 & 32.9 & 5.7 \\
\hline 5 & 5 & 11026.7 & 37.9 & 6.5 \\
\hline \multicolumn{2}{|c|}{ Sub Total } & 29124.9 & 100.0 & 17.3 \\
\hline \multicolumn{2}{|c|}{ Total } & 168653.2 & 100.0 & 100.0 \\
\hline
\end{tabular}


Table 7. Distribution of the soil pits and their classification

Çizelge 7. Toprak profillerinin sınıflandırılması ve dağıımı

\begin{tabular}{|c|c|c|c|c|c|c|c|}
\hline Classification & LF & LU & GF & Classification & LF & LU & GF \\
\hline Lithic Xerorthents & 1 & 3 & Tur & Typic Xerorthents & 3 & 5 & Tur \\
\hline Lithic Xerorthents & 4 & 3 & Tbg & Typic Xerorthents & 4 & 3 & Tbg \\
\hline Lithic Xerorthents & 4 & 4 & Tur & Typic Xerorthents & 4 & 5 & Tu \\
\hline Lithic Xerorthents & 4 & 5 & Tur & Typic Xerorthents & 5 & 3 & Tu \\
\hline Lithic Xerorthents & 5 & 2 & $\mathrm{~Tb}$ & Typic Xerorthents & 5 & 5 & Tha \\
\hline Lithic Xerorthents & 5 & 2 & $\mathrm{Td}$ & Typic Xerorthents & 5 & 5 & Tur \\
\hline Lithic Xerorthents & 5 & 3 & Kye & Typic Xerorthents & 5 & 5 & Tor \\
\hline Lithic Xerorthents & 5 & 3 & Tha & Fluventic Haploxerepts & 4 & 5 & Qa \\
\hline Lithic Xerorthents & 5 & 3 & $\mathrm{Tu}$ & Fluventic Haploxerepts & 4 & 5 & Qa \\
\hline Lithic Xerorthents & 5 & 3 & Tbg & Gypsic Haploxerepts & 2 & 5 & Tur \\
\hline Lithic Xerorthents & 5 & 5 & Oa & Gypsic Haploxerepts & 2 & 5 & Tur \\
\hline Lithic Xerorthents & 5 & 5 & Tha & Typic Calcixerepts & 4 & 5 & Tur \\
\hline Lithic Xerorthents & 5 & 5 & Tur & Typic Calcixerepts & 4 & 5 & Tk \\
\hline Lithic Xerorthents & 5 & 5 & JKs & Typic Calcixerepts & 5 & 4 & Tur \\
\hline Lithic Xerorthents & 5 & 5 & $\mathrm{~Tb}$ & Typic Calcixerepts & 5 & 5 & Tor \\
\hline Typic Psammaquents & 5 & 5 & Qa & Typic Haploxerepts & 2 & 5 & Tur \\
\hline Typic Xerofluvents & 1 & 4 & Qa & Typic Haploxerepts & 3 & 5 & Tur \\
\hline Typic Xerofluvents & 3 & 4 & Qa & Typic Haploxerepts & 4 & 5 & Tor \\
\hline Typic Xerofluvents & 3 & 5 & Qa & Typic Haploxerepts & 5 & 3 & $\mathrm{Ti}$ \\
\hline Typic Xerofluvents & 3 & 5 & Qa & Typic Haploxeralfs & 3 & 3 & Tur \\
\hline Typic Xerofluvents & 3 & 5 & Qa & Typic Haploxeralfs & 4 & 5 & Tha \\
\hline Typic Xerofluvents & 4 & 3 & Qa & Typic Haploxeralfs & 5 & 5 & Tu \\
\hline \multicolumn{8}{|c|}{$\begin{array}{l}\text { JKs : Cherty limestone, Kye: Sandstone, mudstone, limestone, Qa: Alluvium, Tb: Andesite, dacite } \\
\text { Tbg: Granodiorite, Td: Andesite, dacite, tuff, rhyolite, Tha: Sandstone, mudstone, limestone, Ti: } \\
\text { Andesite, basalt, pyroclastic rock, Tk: Breccias, sandstone, mudstone, Tor: Sandstone, breccias, } \\
\text { mudstone, Tu: Basalt, pyroclastic rock, Tur: Breccia, sandstone, shale, gypsum }\end{array}$} \\
\hline
\end{tabular}

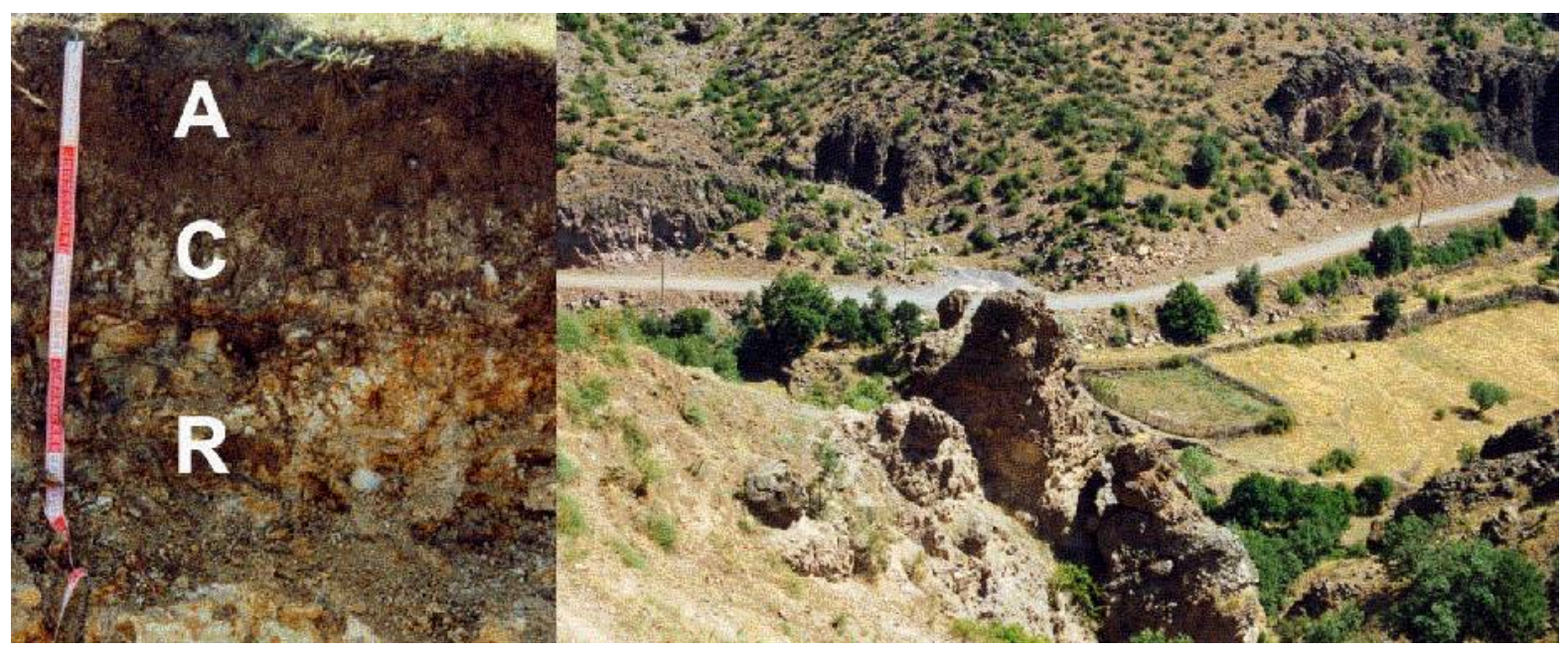

Figure 6. An Entisol soil from study area and its surroundings

Șekil 6. Calıșma alanına ait bir Entisol profili ve çevresi 


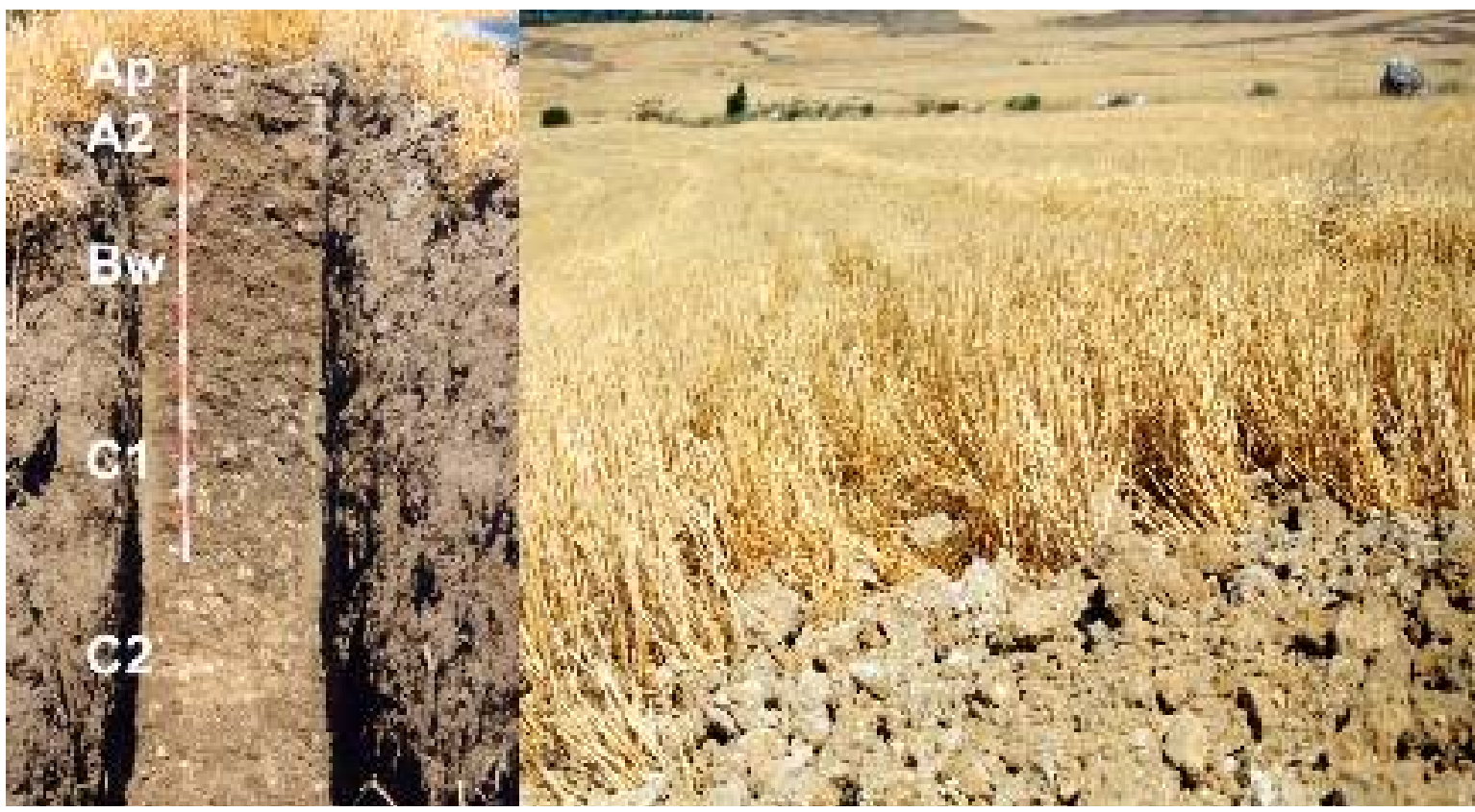

Figure 7. An Inceptisol soil from study area and its surroundings

Șekil 7. Calıșma alanına ait bir Inceptisol profili ve çevresi

As it can be seen from Table 7, 9 subgroups were described in the study area, which were generally in Entisol and Inceptisol soil orders (Figure 6 \& 7). Entisols are dominants of mineral soil materials and do not have distinct pedogenic horizons because of insufficient time for horizons to form as in recent deposits, and occur on slopes where the rate of erosion exceeds the rate of pedogenic horizon formation. The unique properties of Inceptisols are a combination of water availability to plants for more than half of the year and more pedogenic horizons of alteration or concentration with little accumulation of translocated materials.

Except one soil pit, which was described on the narrow colluvial valley, all of the other Lithic Xerorthents formed on hilly and mountainous areas (OPM \& HMO) where higher slopes are. General geological formations from north to south direction are pyroclastics (sensitive to atmospheric conditions), sedimentary (lacustrine and marine) and igneous (granitic intrusion) rocks. In these areas, landform, topographical conditions and high erosion rates were main limiting factors for soil formation. Forest, barren and rangelands were main land uses, and only limited areas were used for the agricultural purposes. Similar results were observed for the Typic Xerorthents. Because of the deeper soil depth developments compared to Lithic
Xerorthents, most of these soils were used for agricultural purposes. All of the Typic Xerofluvents were formed on alluvial (fluvial) parent material and plains (PLA \& PHM). Most of these productive soils were used for agricultural purposes and few areas were used as rangelands. One soil pit was described as Typic Psammeaquent, which is located on narrow Aladag stream flood plain. These areas were especially used for rice growing. Typic Calciexrepts were generally formed on higher plateaus and on the sedimentary (lacustrine and marine) parent material. Undulating topography and carbonate rich parent materials were effective on soil formation. These soils are generally used for agricultural purposes and they have higher productivity.

Typic Haploxerepts were formed on the all landforms where week horizon developments were seen and general parent material was lakustrine and marine originated sediments. Internal soil drainage was main factor for soil formation. Almost all of these soils are used for agricultural purposes. Two soils were classified as Fluventic Haploxerepts, which were formed on alluvial parent materials located on narrow valleys of the hilly and mountainous areas (OPM), showed week structural soil development (Bw). These soils were used for agricultural purposes. Both of the Gypsic Haploxerepts formed on tablelands (TAB) 
and on the sedimentary (lacustrine and marine) rocks. They are generally used for agricultural purposes; however, they have lower productivity compared to Calcixerepts. Physiographic position and gypsum rich parent materials were the main soil forming factors. Typic Haploxeralfs were observed in local areas and generally they were distributed on hilly and mountainous areas. Carbonates were leached deeper or entirely from the profiles in these soils, this process also lead to clay illiviation.

\section{CONCLUSIONS}

The relationship between land cover and landform is of key importance to understanding the effect of physical landscape on biological productivity, stability and diversity, and on natural resource management. However, the spatial complexity of landforms and their associated land covers makes it difficult to comprehend this relationship. Historically, the use of landscape models has shown that landscapes contain a large non-random variability leading to close associations between landform, land cover, land use and soil type. Yet the vast volumes of data needed to understand these relationships and processes have meant that attempts to model landscapes have often been unsuccessful because they were examined only superficially or two-dimensionally.

Despite the problems associated with remotely sensed data, such as variation in images collected on different dates and seasons, and inaccuracies inherent in its interpretation, the results still provide a promising tool for those involved in managing natural resources. Particularly in expansive landscapes, the mapping of landforms and soils is an expensive and time-consuming enterprise. In recent years, the emergence of a broad array of new sensors and earth observation tools, increased access to precise and reliable global positioning systems, and the availability and use of GIS technology offer the prospect of more efficient survey. It is time to re-evaluate what we already know about soil resources. The basis of our observations and the relationships here to be examined and recorded, and brought together the explanations and the experimental results that inform us of soil genesis, soil distribution patterns, and soil behaviour. There remains, however, a significant amount of research and development to be undertaken before this can replace more conventional field survey.

\section{ACKNOWLEDGEMENTS}

The authors acknowledge Scientific and Technical Research Council of Turkey (TUBITAK, project no: TARP 2097) and Ankara University Research Foundation (project no: 20-07-1 1-02) for their valuable support during the course of this research.

\section{REFERENCES}

Anderson J R, Hardy E E, Roach J T and Witmer R E (1976). A Land Use and Land Cover Classification System for Use with Remote Sensor Data. U.S. Geological Survey, Professional Paper 964, pp 28, Reston, VA.

Bayramin I (1998). Integrating Digital Terrain and Satellite Image Data with Soils Data for Small Scale Mapping of Soils. Ph. D. Thesis. Purdue University, Agronomy Department. 121 pages. W. Lafayette, IN 47907

Brabyn L (1998). GIS Analyses of Macro Landform. Presented at SIRC 98 - The 10th Annual Colloquium of the Spatial Information Research Centre, University of Otago, Dunedin, 16-19 November 1998, New Zealand.

Dikau R, Brabb E E, Mark R M (1991). Landform Classification of New Mexico by Computer. U. S. Dept. of the Interior, U. S. Geol. Survey Report 91-634.

Hammond E H (1954). Small-scale continental landform maps: Annals of Assoc. of American Geographers 44, p: 33-42

Helvaci C and Bozkurt S (1994). Geology, mineralogy and petrogenesis of Beypazari (Ankara) granite. Geological Bulletin of Turkey, V. 37, No:2, pp. 31-42.

Horvath E H, Post D F, and Kelsey J B (1984). The relationships of Landsat digital data to the properties of Arizona range lands. Soil Science Society of America Journal. 48, pp. 1331-1334.

Jenny H (1980). The Soil Resource; Origin and behavior. Ecol. Studies 37. Springer-Verlag, NY.

Karadenizli L (1995). Sedimentology of the Upper Miocene - Pliocene gypsum series of the Beypazari Basin, west of Ankara, Central Anatolia, Turkey. Geological Bulletin of Turkey, V. 38, No: 1, pp. 63-74

Klingebiel A A, Horvarth H D, Moore G W, and Reybold U (1987). Use of Slope, Aspect, and Elevation Maps Derived From Digital Elevation Model Data in Making Soil Surveys. Soil Science Society of America, Soil Survey Techniques, SSSA Special Publication, 20, pp. 77-98.

Lee K, Lee G B, and Tyler E J (1 988). Thematic mapper and digital elevation modeling of soil characteristics in hilly terrain. Soil Science Society of America Journal. 52, pp. 104-1 107.

Moore I D, Gessler P E, Nielsen G A and Peterson G A (1993). Soil attribute prediction using terrain analysis. Soil Science Society of America Journal. 57, pp. 443-452.

Shovic H and Mantagne C (1985). Application of a statistical Soil-Landscape Model to an Order III Wildland Soil Survey. Soil. Sci. Soc. Am. J. 49, pp. 961-968.

Siyako F (1 983). Geology report of the Beypazari (Ankara) coal Neogene's basin and surrounding area. Mineral Research Institute Report No: 7431. Ankara. 
Smith D W and Verrill W L (1998). Vernal Pool-SoilLandform Relationships in the Central Valley, California. In C.W. Witham, E.T. Bauder, D. Belk, W.R. Ferren Jr., and R. Ornduff (Editors). Ecology, Conservation, and Management of Vernal Pool Ecosystems - Proceedings from a 1996 Conference. California Native Plant Society, Sacramento, CA. pp. 15-23.

Soil Survey Staff (1993). Soil Survey Manual. USDA Handbook No: 18. U. S. Government Printing Office, Washington, D. C.

Soil Survey Staff (1996). Soil Survey Laboratory Methods Manual, Soil Survey Investigation Report, No: 42, USDA, NRCS, NSSC, Washington, D. C.

Soil Survey Staff (Soil Taxonomy) (1999). A Basic of Soil Classification for Making and Interpreting Soil Survey. U.S.D.A Handbook No: 436, Washington D.C.

Stoner E R, and Baumgardner M F (1981). Characteristic variations in reflectance of soil. Soil Science Society of America Journal, 45, pp. 1161-1165.

Su H, Ransom M D, and Kanemasu E T (1989). Detecting soil information on a native prairie using Landsat TM and SPOT satellite data. Soil Science Society of America Journal. 53, pp. 1479-1483.

Swanson D K (1990). Soil Landform Units for Soil Survey. Soil Survey Horizons, 31, pp. 17-21.

Thornthwaite CW (1948). An approach to a rational classification of climate. Geographical Review 38, pp. 55-94.

Tucker C J, Townshend J R, and Goff T E (1985). African Land-cover classification using satellite data. Science, 227 4685, pp. 367-374. 